\title{
DINÂMICA GEOGRÁFICA DA RIZICULTURA BRASILEIRA NO PERÍODO DA AGRICULTURA CIENTIÍFICA GLOBALIZADA
}

\author{
Luís Fernando Sasseron Agostinho*, Ricardo Abid Castillo
}

\section{Resumo}

Este projeto de iniciação científica busca realizar um levantamento acerca da distribuição espacial das lavouras de arroz no território brasileiro a partir da década de 1990, quando se observa o início de mudanças drásticas na relação entre área plantada e quantidade produzida. Para isso, foram construídos mapas temáticos nas escalas do território e das regiões produtivas agrícolas identificadas e discutidos os resultados obtidos a partir da pesquisa bibliográfica e da manipulação do banco de dados da Pesquisa Agrícola Municipal do IBGE. O que se constatou foi a concentração da produção brasileira de arroz na região Sul do país e o desenvolvimento de cultivares cada vez mais rentáveis e tenológicas. $\mathrm{O}$ arroz é um cereal de grande importância para a segurança alimentar da população humana e comprender o papel do Brasil como o único país fora do continente asiático a contribuir com um dos dez maiores valores em quantidade produzida é um importante exercício de reflexão para o território brasileiro.

\section{Palavras-chave:}

Arroz, Território Brasileiro, Agricultura Globalizada

\section{Introdução}

Utilizando a base de dados da Pesquisa Agrícola municipal realizada pelo IBGE e com apoio de material bibliográfico construiu-se uma investigação para caracterizar a dinâmica geográfica da rizicultura brasileira no período da agricultura científica globalizada (Santos, 2000). Para isso, foram realizados tratamentos gráficos e cartográficos a nível nacional e regional entre os anos de 1992 e 2017, período em que se observou um aumento de $24,6 \%$ na quantidade produzida do cereal, apesar da queda de $41,2 \%$ em seu valor de área plantada.

\section{Resultados e Discussão}

O que se observou para o território brasileiro neste período foi a concentração da atividade rizícola na região Sul do país, responsável por $80,4 \%$ da produção brasileira de arroz (IBGE, 2017). O mapa abaixo foi construído com base nos valores de rendimento médio da produção e nele podemos verificar a existência de três Regiões Produtivas Agrícolas (ELIAS, 2011) - Rio Grande do Sul, Oeste de Tocantins e Norte de Roraima todas com aptidão à cultura do arroz irrigado (CONAB, 2015).

Mapa 1. Rendimento médio da produção do arroz em casca por microrregião geográfica - 2017

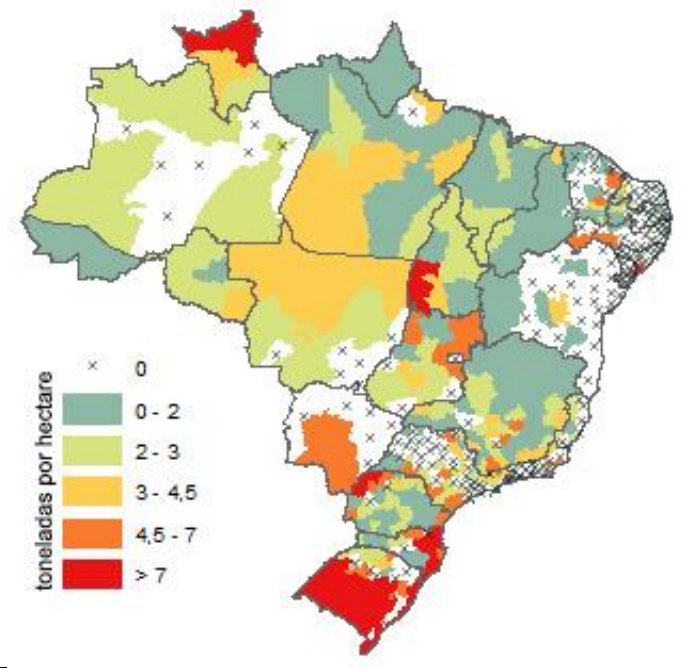

O arroz de sequeiro - não irrigado - é produzido na região Centro-Oeste, no entanto, perde espaço para culturas mais rentáveis como a soja, apenas desempenhando o papel de cultura pioneira (VILLAR \& FERREIRA, 2005).

Outras constatações do trabalho foram a diminuição do consumo brasileiro per capita de arroz, que entre 1990 e 2010 passou de 40,7 para 33,5 kg/hab/ano (FAO, 2010), e o crescimento da produção a uma taxa inferior a da população, sugerindo mudanças nos padrões e hábitos de consumo do cereal. Alertamos também para a existência de uma dupla tendência na evolução do consumo de arroz no país, que aumenta junto à renda nas classes baixas, e diminui nas classes altas (BARATA, 2005). Por fim, merece destaque o papel desempenhado pelas empresas agrícolas como EMBRAPA e o Instituto Rio-grandense do Arroz (IRGA) que dispensam recursos para a pesquisa e 0 desenvolvimento de cultivares mais rentáveis e de maior aplicabilidade no território brasileiro.

\section{Conclusões}

A atual dinâmica geográfica da rizicultura brasileira vem sendo caracterizada pela concentração da produção na região Sul e pelo desenvolvimento de cultivares mais rentáveis e tecnológicas. $O$ arroz é um cereal de fundamental importância para a segurança alimentar da população humana e o Brasil vem cumprindo seu papel como o maior produtor do cereal na América Latina.

\section{Agradecimentos}

Ao orientador Ricardo Castillo pela atenção dispensada e ao CNPq pela concessão da Bolsa de Pesquisa.

\footnotetext{
BARATA, Tiago Sarmento. Caracterização do consumo de arroz no Brasil. In: CONGRESSO BRASILEIRO DE ECONOMIA E SOCIOLOGIA RURAL, XLIII. 2005

CONAB. A cultura do arroz. Brasília: Conab, 2015.

ELIAS, Denise. Agronegócio e novas regionalizações no Brasil. Revista Brasileira de Estudos Urbanos e Regionais, v. 13, n. 2, 2011.

FAO. FAOSTAT. 2015

IBGE. Pesquisa Agrícola Municipal. 2017

MENDEZ DEL VILLAR, Patricio; FERREIRA, Carlos Magri. Dinâmicas territoriais do arroz de terras altas na região Centro-Oeste do Brasil. Cadernos de Ciência e Tecnologia, v. 22, n. 1, p. 97-107, 2005.

SANTOS, M. Por uma outra globalização. Rio de Janeiro: Record, 2000
} 